\title{
Why Indonesia Should Keep Joining in Trade and Investment Agreements?
}

\author{
I Gusti Ngurah Parikesit Widiatedja*, I Gusti Ngurah Wairocana, I Nyoman Suyatna \\ Faculty of Law, Udayana University, Indonesia. \\ * Corresponding author E-mail: ngurahparikesit@gmail.com
}

\author{
ARTICLE INFO \\ Keywords: \\ Investment; \\ Investment Agreements; \\ Joining Agreements; \\ Trade Agreements \\ How to cite: \\ Widiatedja, I.G.N.P., \\ Wairocana, I.G.N., Suyatna, \\ I.N. (2019). "Why Indonesia \\ Should Keep Joining in \\ Trade and Investment \\ Agreements?," Hasanuddin \\ Law Review, 5(1): 1-18 \\ DOI: \\ 10.20956/halrev.v5i1.1430
}

\begin{abstract}
There have been some concerns over the existence of trade and investment agreements. They have been doubted because of the poverty and inequality issues in some regions across the globe. The rise of the spirit of national interest of their members has also exacerbated the situation. Hence, these two miserable facts may end up with a question whether Indonesia should keep joining trade and investment agreements. This article is aimed to examine if Indonesia should continue its participation in trade and investment agreements. Employing a normative legal research, this article put three parameters, analysing the continuity of Indonesia's participation, namely the benefits of international trade and foreign direct investment, the rationale of trade and investment agreements, and how trade and investment agreements (that involve Indonesia) have positively affected Indonesia's development. This article then claims that Indonesia should keep joining trade and investment agreements for realising its targets on economic growth and development.
\end{abstract}

Copyright (C) 2019 HALREV. All rights reserved.

\section{Introduction}

There have been some concerns, doubting the contribution of trade and investment agreements on the country's economic growth and development. In the nearly half of world's population, inequality and poverty are still rampant. 1 United Nations Development Program (UNDP) in 2015 showed an inequality related to human development, ${ }^{2}$ especially when almost all regions achieved a medium level of human development, Sub Saharan Africa still faced a low-level of development. ${ }^{3}$ Muhammad

1 Yong-Shik Lee. “Law and Development for Least Developed Countries Theoretical Basis and Regulatory Framework for Microtrade". in Yong-Shik Lee et al (eds). (2011). Law and Development Perspective on International Trade Law. Cambridge: Cambridge University Press, p. 8.

2 United Nations Development Programme. (2015). Human Development Report 2015. Geneva: UNDP, p. 58.

$3 \quad$ Ibid. p.65. 
Yunus, a Nobel Peace Prize winner, stated that income inequality was a murky reality, pointing "ninety-four percent of the world income goes to 40 percent of the population while sixty percent of people live on only 6 percent of world income". ${ }^{4}$ Some scholars then express their concerns, arguing that trade and investment agreements have adversely affected environment ${ }^{5}$ and cultural value and heritage. ${ }^{6}$

Some leading scholars then countered above-mentioned facts by stating that the existence of national laws and policies has significantly determined the extent to which a country's success or failure to benefit from trade and investment agreements. Hernando De Soto (2000) claimed that formalities and inefficiencies in the legal systems of developing countries have made them fail to enjoy the benefits of capitalism. ${ }^{7}$ Trubek (2006) then identified how legal cultures of developing countries were highly 'formalist', leading to weak enforcement, inappropriate rules, and low legitimacy. ${ }^{8}$ Dee and Findlay (2009) then showed how national laws are more influential than international laws in particular areas, such as trade in services as it mainly deals with 'behind the border' issue. ${ }^{9}$

The spirit of national interest also threatens the existence of trade and investment agreements, looking at their failures to conclude significant trade and investment deals. ${ }^{10}$ Specifically, the failure of the Doha Development Agenda (DDA) because of the unresolved disagreement between developed countries and developing countries on issues relating to, among other things, trade remedies and agriculture. ${ }^{11}$ Some countries' domestic policies also worsen the situation. For example, some EU's member added trade hindrances to cross-border mergers owing to of the distress of losing national vanity and jobs. ${ }^{12}$ Similarly, the new president of USA, Donald J Trump undertakes antidumping measures to unilaterally condemn any countries or companies whose products are damaging domestic producers. ${ }^{13}$ Indonesia itself has employed several non-tariff barriers (NTBs), such as import licenses and export restrictions despite it has successfully

4 Muhammad Yunus. (2006). "Nobel Lecture". Available online from: http://nobelprize.org/ nobel_prizes/peace/laureates/2006/yunus-lecture-en.html [Accessed November 7, 2017].

5 Daniel Bodansky, Jessica C Lawrence. “ Trade and Environment” in Daniel Bethlehem et al (eds.). (2009). The Oxford Handbook of International Trade Law. Oxford: Oxford University Press, p. 508. See also I Gusti Ngurah Parikesit Widiatedja and I Gusti Ngurah Wairocana. (2017). “The Lack of the Environmental Concern in Indonesia's Bilateral Investment Treaties". Hasanuddin Law Review 3(3):231.

6 Oliver R Goodenough. (1998). "Defending the Imaginary to the Death?: Free Trade, National Identity, and Canada's Cultural Preoccupation". Arizona Journal of International Law and Comparative Law 15, p. 226.

7 Hernando De Soto. (2000). The Mystery of Capital: Why Capitalism Triumphs In The West and Fails Everywhere Else. London: Penguin Books, p. 37.

8 David M Trubek. "The "Rule of Law" in Development Assistance: Past, Present, and Future" in David Trubek and Alvaro Santos (eds). (2006). The New Law and Economic Development: A Critical Appraisal. Cambridge: Cambridge University Press, p. 76.

9 Philippa Dee and Christopher Findlay, "Services in PTAs - donuts or holes?" in Sisira Jayasuria, Donald MacLaren and Gary Magee. (2009). Negotiating a Preferential Trading Agreement: Issues, Constraints and Practical Options. Leiden: Edward Elgar, p. 97-98.

10 I Gusti Ngurah Parikesit Widiatedja and I Gusti Ngurah Wairocana. (2017). "The Rise of the Spirit of National Interest and the Existence of World Trade Organization Agreement: A Case Study of Indonesia". Padjajaran Journal of Law 4(2):319.

11 BBC News. (2008). "World Trade Talks End in Collapse". Available from: http://news.bbc.co.uk/2/ hi/business/7531099.stm. [accessed November 21, 2017].

12 Raymond J. Ahearn. (2006). “Europe: Rising Economic Nationalism?”. CRS Report for Congress. Available from: http://research.policyarchive.org/4378.pdf. [Accessed November 11, 2017].

13 World Policy. (2017). "Trump and Trade Bilateralism". Available from: http://www.worldpolicy.org/ blog/2017/01/12/trump-and-trade-bilateralism [Accessed September 14, 2017]. 
reduced its tariffs. ${ }^{14}$ In investment agreements, some countries terminated their agreements, showing their lack of interest to participate in those agreements. For example, Indonesia had 13 Bilateral Investment treaties (BITs) that were due to expire during 2015 and 2016, and the government declared its measure to not renew 12 BITs when they expired. 15

The questionable contribution of trade and investment agreements along with the rise of the spirit of national interest from their member states may end up with the questions whether Indonesia should keep joining in trade and investment agreements. This paper, however, argues that Indonesia should keep joining in trade and investment agreements by looking at the benefits of international trade and foreign direct investment, the rationale of trade and investment agreements, and how they have affected Indonesia's development.

This paper starts by explaining the theory and evidence of the benefits of international trade and foreign direct investments, showing how they have contributed to a country's economic growth and development. This paper then turns to analyse the rationale of trade and investment agreements, covering how they can avoid armed conflict; how they have implemented non-discriminatory principle, how they have provided differential treatments for developing countries, and how they have a fair and independent dispute settlement process. Next, this paper explains the positive impact of trade and investment agreements for Indonesia, focusing the impact on trade and investment flows, and development.

\section{The Benefits of International Trade and Foreign Direct Investment: Theory and Evidence}

\subsection{The Interplay between International Trade and Foreign Direct Investment}

Trade and investment are highly connected that could be illustrated as two sides of the same coin. ${ }^{16}$ Companies conduct cross-border trade to supply their foreign investment, 17 and they invest abroad to bolster their trade.18 Moreover, in the liberalisation era, while investors produce and consume both goods and services, an open trading system will provide a bright investment climate. ${ }^{19}$ Equally important, international trade and foreign investment have similar dominant actors through the presence of multinational enterprises. ${ }^{20}$

14 Margit Molnar and Molly Lesher, "Indonesia" in OECD. (2008). Globalisation and Emerging Economies: Brazil, Russia, India, Indonesia, China, and South Africa. Paris: OECD, p. 334.

15 See Indonesia for Global Justice. (2015). "Indonesia Sudah Menghentikan 18 BITs". Available From: http://igj.or.id/en/indonesia-sudah-menghentikan-18-bits/. [Accessed November 2, 2017].

16 Debra P Steger. “International Trade and Investment: towards a Common Regime?" in Roberto Echandi, Pierre Sauve (eds). (2013). Prospects in International Investment Law and Policy. Cambridge: Cambridge University Press, p. 159.

17 Nicholas DiMascio, Joost Pauwelyn. (2008). "Nondiscrimination in Trade and Investment Treaties: Worlds Apart or Two Sides of the Same Coin". American Journal of International Law, 102: 48.

18 Jeswald W Salacuse. (2013). The Three Laws of International Investment: National, Contractual, and International Frameworks for Foreign Capital, Oxford: Oxford University Press, p. 23.

19 Erik Denters, "Preferential Trade and Investment Treaties" in Tarcisio Gazzini and Eric De Brabandere (eds). (2012). International Investment Law: The Sources of Rights and Obligations, Leiden: Martinus Nijhofff Publishers, p. 51.

20 Christian Tietje, "Perspectives on the Interaction Between International Trade and Investment Regulation" in Roberto Echandi, Pierre Sauve (eds). (2013). Prospects in International Investment Law and Policy, Cambridge: Cambridge University Press, p.167. 
From a government perspective, when the government enacts policy, it is not purely designed for reaching trade or investment objectives, for example, in the case of subsidy program..$^{21}$ In addition, the close connection of trade and investment is also reflected from the existing regulation that become more converged. ${ }^{22}$ Through its binding treaties, the WTO has applied many rules covering not only trade but also investment as reflected in the GATS.23 Besides, some preferential trade agreements, such as North America Free Trade Agreement (NAFTA) and Trans-Pacific Partnership Agreement (TPP) have also separately regulated investment and investment arbitration. Contrarily, trade became integrated into investment treaties. ${ }^{24}$ Some existing BITs encompassing not only protection but also access or entry rights. ${ }^{25}$ Besides, they also forbid trade-related performance requirements, especially provision to require the use of local products and transfer of technology.26

\subsection{The Benefits of International Trade and Foreign Direct Investment}

\subsubsection{The Benefits of International Trade}

Theoretically, Adam Smith in The Wealth of Nations carved out how international trade provided benefits by explaining that:

"If a foreign country can supply us with a commodity cheaper than we ourselves can make it, better buy it of them with some part of the produce of our own industry, employed in a way in which we have some advantage. The general industry of the country ... . will not thereby be diminished, no more than the above-mentioned artificers; but only left to find out the way in which it can be employed with the greatest advantage. It is certainly not employed to the greatest advantage, when it is thus directed towards an object which it can buy cheaper than it can make." 27

David Ricardo then denoted 'comparative advantage' theory in his book "On the Principles of Political Economy and Taxation" in 1817.28 Imagining the economy of the world only comprised Portugal and England with only wine and cloth were available, he then argued that:

"England may be so circumstanced, that to produce the cloth may require labour of 100 men for one year, and if she attempted to make wine, it might require the labour of 120 men for the same time. England would therefore find it her interest to import wine, and to purchase it by the exportation of cloth. To produce the wine in Portugal might require only the labour of 80 men for one year, and to produce the cloth in the same country might require the labour of 90 men for the same time. It would therefore be advantageous for her to export wine in exchange for cloth."29

21 Debra P. Steger, Loc.Cit.

22 Friedl Weiss, “Trade and Investment Law: What Relation?” In Giorgio Sacerdoti, et al. (eds). (2014). General Interest of Host State in International Investment Law. Cambridge: Cambridge University Press, p.78.

23 Marrakesh Agreement Establishing the World Trade Organization, opened for signature 15 April 1994 (entered into force 1 January 1995) annex 1B ('General Agreement on Trade in Services') Art I(2)(c)

24 Joost Pauwelyn. (2014). "The Re-Convergence of International Trade and Investment Law: Causes, Questions, and Reform". (2014). American Society of International Law Proceeding, 108:255.

25 Ibid.

26 Ibid.

27 Adam Smith. (1976). An Inquiry into the Nature and Causes of the Wealth of Nations, Chicago: University of Chicago Press, p. 478.

28 David Ricardo. (1951). On the Principles of Political Economy and Taxation, Cambridge: Cambridge University Press, p. 135.

29 Ibid. 
Sketchily, according to this theory, international trade, has promised benefits by enabling corporations in a particular state for specializing its production, leading to cheaper products, and helping limited income consumers to buy a greater variation of those products. ${ }^{30}$

International trade has generated significant benefits. Through the liberalised trading system, trade can provide more jobs in the short term without reducing jobs in foreign countries, yielding income gains in the long term. ${ }^{31}$ In addition, many firms can access a broader and more efficient various imported materials, skills, and technology, resulting in substantive productivity gains. ${ }^{32}$ Moreover, international trade can support the Sustainable Development Goals ('SDGs') especially in order to alleviate poverty and hunger. ${ }^{33}$ In particular, imports have reduced the burden of poverty by enhancing competition and enabling low-income consumers to purchase greater variety of less expensive goods. ${ }^{34}$

International trade has also provided benefits to increase real GDP. It allows firms to specialise in the production, resulting more cheaply products, and then creating country's comparative advantages. ${ }^{35}$ Besides, trade allows firms to maximise economies of scale from the firms that operate overseas and have extended their market size. ${ }^{36}$ Equally important, according to the WTO data, how international trade considerably influence today's GDP was reflected from the increase of the average share of exports and imports of goods and commercial services in world GDP from 20 per cent in 1995 to 30 per cent in $2014 .{ }^{37}$

\subsubsection{The Benefits of Foreign Direct Investment}

John H Dunning introduced an eclectic approach in 1977, indicating that three sources of advantage-namely ownership, location and internalisation-influenced a firm's decision to conduct production abroad. ${ }^{38}$ The ownership advantage referred to intangible factors, including intellectual property rights, entrepreneurial capacity, and production methods, which might enhance the competitive advantages of firms engaging in FDI. ${ }^{39}$ The location advantage referred to factors in a host country such as the availability of raw materials, the level of wages, the taxation policy and incentives offered by host governments..$^{40}$ Finally, the internalisation advantage referred to direct involvement in the production process rather than a contractual partnership through licensing or a joint venture. ${ }^{41}$

30 WTO, "World Trade Report 2014 Trade and Development: Recent Trends and The Role of the WTO", Loc.cit.

31 The Organization for Economic Cooperation and Development. (2011). "The Impact of Trade Liberalisation on Jobs and Growth: Technical Note". OECD Trade Policy Papers, 107: 34.

32 Przemyslaw Kowalski, Max Büge Kowalski, P. and M. Büge. (2013). “Assessing the Trade-Related Sources of Productivity Growth in Emerging Economies". OECD Trade Policy Papers, 158: 44.

33 World Trade Organization, (2014)'World Trade Report 2014 Trade and Development: Recent Trends and The Role of the WTO'. Available from: https://www.wto.org/english/res_e/booksp_e/world_trade_report14_e.pdf [Accessed November 12, 2017].

34 Ibid.

35 Ibid.

36 Ibid.

37 Ibid.

38 John H. Dunning. (1977). The International Allocation of Economic Activity. London: Palgrave Macmillan, p. 63.

39 Ibid., p. 64.

$40 \quad$ Ibid., p. 69.

$41 \quad$ Ibid., p.107. 
Scholars then developed the theory of outward investment based on perfect competition. MacDougall (1960) stated that when the free movement of capital from a home country to a host country took place, the marginal productivity of capital would be eventually equalised between the two countries. 42 Feldstein and Horioka, then specified that the movement of capital mainly came from "capital-rich, low-interest-rate" countries to "higher interest rates and a lower capital stock" countries. ${ }^{33}$ This mechanism took place until the capital stock and interest rates had achieved equal position. ${ }^{44}$ After investing abroad, the home country's output fell without any downturn in the national revenue because the home country gained higher revenue in the long period. 45 This theory based on precondition that capital is identical between different sites and firms and the process of transferring international capital has no barriers. ${ }^{46}$

The presence of FDI has contributed huge benefits related to economic development for host countries, encompassing job opportunities, transfer of technology, productivity and export improvement. Firstly, FDI has created job opportunities that are crucial for reducing unemployment and poverty in host countries. For instance, Richards and Schaefer stated that foreign-owned American firms employed 6.1 million people 47 and 2.4 million indirect and induced jobs, resulting a total of 8.5 million jobs in 2013.48

FDI has also contributed to the transfer of new and sophisticated technology that may accelerate and improve production and distribution methods of local firms. Specifically, contractual relationships between foreign and local firms through licensing, franchising, services outsourcing and other typical forms, creating a huge opportunity for fostering transfer of technology.49 In Jordan, the collaboration between foreign and local firms has assisted Jordanian firms to earn the competitive advantage in order to enter international markets. 50

\section{The Rationale of Trade and Investment Agreements}

\subsection{Trade and Investment Agreements Can Mitigate Armed Conflict}

From a historical perspective, one of the reasons why the armed conflict occurred was the reluctance of countries to undertake trade co-operation. Specifically, the existence of trade coalition, which deliberately imposed protectionist policy, exacerbated the conflict. ${ }^{51}$ A study from Gowa and Hicks indicated that the trade blocs during World

42 GDA MacDougall. (1960). “The Benefits and Costs of Private Investment from Abroad: A Theoretical Approach'. Economic Record, 36: 25

43 Martin Feldstein and Charles Horioka. (1980). "Domestic Savings and International Capital Flows". Economic Journal, 90:314-329.

44 Ibid.

45 GDA MacDougall, Loc.Cit.

$46 \quad$ Ibid, p. 27.

47 Julian Richards and Elizabeth Schaefer. (2016). Jobs Attributable to Foreign Direct Investment in the United States. Available from: http://www.trade.gov/mas/ian/build/groups/public/@tg_ian/documents/webcontent/ tg_ian_005496.pdf_[accessed December 11, 2017].

48 Ibid.

49 Roberto Echandi, Jana Krajcovicova, Christine Zhenwei Qiang. (2015). “The Impact of Investment Policy in a Changing Global Economy: A Review of the Literature", World Bank Policy Research Working Paper, 7437, p.3.

50 Zu'bi MF Al-Zu'bi et al. (2012). “Investigating the Effect of Foreign Direct Investment Technology Transfer on Mass Customization Capability in Jordan's Manufacturing Sector". International Research Journal of Finance and Economics, 94:84.

51 Joanne Gowa and Raymond Hicks. (2013). "Politics, Institutions and Trade: Lessons of the Interwar Era". International Organization, 67:440. 
War I and the Great Depression triggered high political tension among countries, leading to World War II.52 Learning from this experience, a country that apply trade openness instead of trade blocs will have a greater opportunity to forestall and resolve conflict within their borders. ${ }^{53}$

The existence of trade and investment agreements is important to reach world's peace and stability. When governments concluded agreements, it was not only to reach economic prosperity but also security. ${ }^{54}$ For instance, one of the objectives of the Association of Southeast Asian Nations (ASEAN) 1967 is to "promote regional peace and stability through abiding respect for justice and the rule of law in the relationship among countries of the region and adherence to the principles of the United Nations Charter." 55 Besides, Comprehensive Economic and Trade Agreement (CETA) between Canada and the European Union recognises "the importance of international security, democracy, human rights and the rule of law for the development of international trade and economic cooperation."56 Trade and investment agreements can mitigate conflict and reduce the risk of a militarised action although these issues are not always expressly stated in treaties' objectives. ${ }^{57}$ In particular, a study from Lee and Pyun stated that an increase in bilateral trade interdependence and global trade integration significantly promotes peace between countries from 1950 to 2000.58 Beyene also supported this argument, showing how bilateral trade relationship significantly minimise the probability of violence in East Africa. 59

Similar to trade, the co-operation among countries to promote and protect FDI will contribute to the more peaceful situation although this issue is not always expressly stated in investment agreements. The presence of FDI has a positive impact in boosting economic development, ${ }^{60}$ whereby reducing the likelihood of armed conflict. Polachek and Xiang scrutinised the connection of FDI and conflict as the growth of FDI, to some extent, exceeded international trade. 61 They revealed that the presence of FDI has 'a

52 Ibid.

53 Robert G Blanton and Clair Apodaca. (2007). “Economic Globalization and Violent Civil Conflict: Is Openness a Pathway to Peace?" The Social Science Journal, 44:605.

54 Yoram Z Haftel, "Trade Agreements, Violent Conflict and Security" in Andreas Dur, Manfred Elsig (eds). (2015). Trade Cooperation: The Purpose, Design and Effects of Preferential Trade Agreements. Cambridge: Cambridge University Press, p.313

55 The Association of Southeast Asian Nations (ASEAN), The ASEAN Declaration, 8 August 1967. Availble from: http://asean.org/the-asean-declaration-bangkok-declaration-bangkok-8-august-1967 [Accessed January 19, 2018].

56 Comprehensive Economic and Trade Agreement (CETA) between Canada, of the one part, and the European Union and its member states, signed 26 September,2014, the Preamble.

57 Edward D Mansfield, "Preferential Peace: Why Preferential Trade Arrangements Inhibit Inter-state Conflict" in Edward D Mansfield and Brian M. Pollins (eds). (2003). Economic Interdependence and International Conflict: New Perspectives on an Enduring Debate. Michigan:University of Michigan Press, $\mathrm{p}$. 223.

58 Jong-Wha Lee and Ju Hyun Pyun, (2009). “Does Trade Integration Contribute to Peace'.Working Paper Series on Regional Economic Integration No.24, Asian Development Bank, p. 3.

59 Hailay Gebretinsae Beyene. (2015). "Does International Trade Reduce Political Disputes?". Foreign Trade Review, 50: 114.

60 Laura Alfaro et al. (2004). "FDI and Economic Growth: The Role of Local Financial Markets". Journal of International Economics, 64:93

61 Solomon Polachek and Jun Xiang. (2010). "How Opportunity Costs Decrease the Probability of War in an Incomplete Information Game". International Organization, 64:133. 
pacifying effect' to mitigate international conflict. ${ }^{62} \mathrm{~A}$ study from Bussmann supported this argument, indicating that FDI reduce 'the risk of an outbreak of a fatal dispute'.63

\subsection{Trade and Investment Agreements Implement Non-Discriminatory Principle}

During the Great Depression of the 1930s, many countries undertook discriminatory trade policies, leading to economic and political crises. ${ }^{64}$ This situation became one of the major contributing factors of the World War II.65 Thus, the existence of the trade and investment treaties that implement non-discriminatory principle is very crucial for managing trade relations among countries. The preamble of the WTO mentioned that the core objective of the multilateral trading system is "the elimination of discriminatory treatment in international trade relations." 66

To illustrate the objective of the non-discriminatory principle, the Appellate Body in EC - Banana III ruled that:

"The essence of the non-discrimination obligation is that like products should be treated equally, irrespective of their origin. As no participant disputes that all bananas are like products, the non-discrimination provision apply to all imports of bananas, irrespective of whether and how a Member categorises or subdivides these imports for administrative or other reasons." 67

Supporting the provision from the GATT, Article 2.3 of the Trans-Pacific Partnership Agreement (TPP) expressly mentioned that:

"Each Party shall accord national treatment to the goods of the other Parties in accordance with Article III of GATT 1994, including its interpretative notes, and to this end, Article III of GATT 1994 and its interpretative notes are incorporated into and made part of this Agreement, mutatis mutandis".68

The implementation of the non-discriminatory principle has also covered bilateral investment treaties. In paticular, article 3 (1) of the US Model Bilateral Investment Treaty 2012 requires 'national treatment' as follows:

"Each Party shall accord to investors of the other Party treatment no less favourable than that it accords, in like circumstances, to its own investors with respect to the establishment, acquisition, expansion, management, conduct, operation, and sale or other disposition of investments in its territory."69

62 Ibid.

63 Margit Bussmann. (2010). "Foreign Direct Investment and Militarized International Conflict". Journal of Peace Research, 47(2): 143.

64 Peter Van Den Bossche. (2010). The Law and Policy of the World Trade Organization: Text, Cases and Materials. Cambridge: Cambridge University Press, p. 321.

65 Ibid.

66 Andrew D Mitchell and Nicolas JS Lockhart. “Ensuring Compliance between a Bilateral PTA and the WTO" in Sisira Jayasuria, Donald MacLaren and Gary Magee (eds). (2009). Negotiating a Preferential Trading Agreement: Issues, Constraints and Practical Options. Cheltenham: Edward Elgar, p.235.

67 Appellate Body Report, European Communities - Regime for the Importation, Sale and Distribution of Bananas, WT/DS27/AB/R (25 September 1997) Para 190.

68 Trans-Pacific Partnership. (opened for signature 5 November 2015, not yet entered into force) art. 2.3.

69 The United States Model Bilateral Investment Treaty 2012, art 3 (1). 
Almost all Indonesia's BITs provides non-discriminatory principle. For example, Indonesia-Malaysia BIT in 1994 explains that:
"Investments made by investors of either Contracting Party in the territory of the other Contracting Party and/or returns accrued, shall receive treatment which is fair and equitable, and not less favourable than that accorded to any third State." 70

\subsection{Trade and Investment Agreements Have Special and Differential Treatments for Developing Countries}

The importance of trade and investment agreements is also related to the application of special and differential treatment for developing countries, recognising the specific needs to pursue their economic development. The Preamble of WTO then emphasize in its preamble that recognise:

"...there is need for positive efforts designed to ensure that developing countries, and especially the least developed among them, secure a share in the growth in international trade commensurate with the needs of their economic development."71

One of the provisions that provide special and differential treatment is found under Article XXXVI (8) of the GATT. It stated that "The developed contracting parties do not expect reciprocity for commitments made by them in trade negotiations to reduce or remove tariffs and other barriers to the trade of less-developed contracting parties."72

The ASEAN-Australia-New Zealand Free Trade Area (AANZFTA) also consider the importance of the special and differential treatment for developing countries. Its preamble stated that:

"Considering the different levels of development among ASEAN Member States and between ASEAN Member States, Australia and New Zealand and the need for flexibility, including special and differential treatment, especially for the newer ASEAN Member States; as well as the need to facilitate the increasing participation of newer ASEAN Member States in this Agreement and the expansion of their exports, including, inter alia, through strengthening of their domestic capacity, efficiency and competitiveness."73

In 1988, Indonesia involved in what have been called Global System of Trade Preference (GSTP) under the framework of UNCTAD, consisting of 77 developing countries. ${ }^{74}$ The objective of this agreement was 'to promote and sustain mutual trade, and the development of economic co-operation among developing countries, through exchange of concessions'. 75

Because special and differential treatments for developing countries take many forms, Van Den Bossche then divided these treatments into six types: the provision to enhance the trade opportunities of developing countries; the provision regulating developed

70 Agreement Between the Government of the Republic of Indonesia and the Government of Malaysia, signed 22 January 1994 (terminated) art 3 ('Indonesia-Malaysia BIT').

71 Marrakesh Agreement Establishing the World Trade Organization, the Preamble.

72 GATT. Art. XXXVI (8)

73 Agreement establishing the ASEAN-Australia-New Zealand Free Trade Area ('AANZFTA'), signed 27 February 2009, the Preamble.

74 Agreement on the Global System of Trade Preferences among Developing Countries, signed 13 April 1988 (entered into force 22 October 1989) the preamble.

75 Agreement on the Global System of Trade Preferences among Developing Countries, signed 13 April 1988 (entered into force 22 October 1989) art 2. 
countries to safeguard developing countries' interest; the flexible commitments, of action and employ of policy tools; interposed time periods; technical assistance; and the least developed countries' regulation. ${ }^{76}$

\subsection{Trade and Investment Agreements Have A Fair Enforcement Mechanism}

\subsubsection{Trade agreements have established rules-oriented dispute settlement}

Although international courts may not be able to force governments to obey their decisions, 77 dispute settlement mechanism has a crucial role for enforcing the commitments made under trade agreements. ${ }^{78}$ Without having this process, any trade agreements would not have been concluded.79 Matsushita stated that trade agreements entail trade rules and enforcement in the sense that a trade agreement alone would not be inadequate to prevent and abolish the tendency of states to diverge from or to negate market access commitments. 80

Some trade treaties, such as WTO and NAFTA, have provided more rules-oriented dispute settlement process through the application of judicial settlement and arbitration (not just diplomatic means). ${ }^{81}$ This method promises a just and fair solution, putting all members in the equal position. ${ }^{82}$ For example, developing countries successfully defeated superpower countries in some WTO cases. In particular, US - Underwear, a complaint by Costa Rica, ${ }^{83}$ US - Clove Cigarettes, ${ }^{84}$ a complaint by Indonesia and even more so US - Gambling, a complaint by Antigua which has a population only $67,000.85$

The next rationales for trade agreements is that the freedom to manage court proceeding. Under WTO and PTAs adjudication process, courts and tribunals entitle what have been regarded as 'inherent powers', 86 including 'the power to manage the proceedings to the extent necessary to fulfil their adjudicative function' ${ }^{87}$ Having obtained these rights, courts and tribunals could freely consider what evidence to concede and how to weigh that evidence 88 thereby enabling them to decide more accurate and rules-oriented rulings. Equally, trade agreements provide a direct mechanism for member by which it

76 Peter Van Den Bossche, op.,cit., p.737.

77 Karen J Alter. (2014). The New Terrain of International Law: Courts, Politics, Rights. New Jersey: Princeton University Press, p. 32.

78 World Trade Organisation Secretariat. (2007). World Trade Report 2007: Six Decades of Multilateral Cooperation - What Have We Learned?. Geneva: WTO, p. 155.

79 Ibid.

80 Mitsuo Matsushita et al. (2003). The World Trade Organization: Law, Practice, and Policy. Oxford: Oxford University Press $3^{\text {rd }}$ ed, p.8.

81 J.G Merrills. (2011). International Dispute Settlement. Cambridge: Cambridge University Press $5^{\text {th }}$ ed, p. 83.

82 Hanspeter Neuhold. (2015). The Law of International Conflict: Force, Intervention and Peaceful Dispute Settlement. Leiden: Brill Nijhoff, p. 203.

83 Appellate Body Report, United States - Restrictions on Imports of Cotton and Man-made Fibre Underwear, WT/DS24/AB/R (25 February 1997) [11] ('US-Underwear').

84 Appellate Body Report, United States - Measures Affecting the Production and Sale of Clove Cigarettes, WT/DS406/AB/R (24 April 2012) [5751] ('US- Clove Cigarettes').

85 Appellate Body Report, United States - Measures Affecting the Cross-Border Supply of Gambling and Betting Services, WT/DS285/AB/R (20 April 2005) [5663] ('US-Gambling').

86 Andrew Mitchell and David Heaton. (2010). "The Inherent Jurisdiction of WTO Tribunals: The Select Application of Public International Law Required by the Judicial Function". Michigan Journal of International Law, 31: 561.

87 Michelle Grando. (2009). Evidence, Proof and Fact-Finding in WTO Dispute Settlement. Oxford: Oxford University Press, p. 54

88 Tania Voon. (2015). “Evidentiary Challenges for Public Health Regulation in International Trade and Investment Law". Journal of International Economic Law, 18:800. 
can file lawsuit to another member without any prior consent. Specifically, under the WTO dispute settlement scheme, whenever a member wants to submit a complaint against another WTO member, it can request the WTO's dispute settlement, without requiring the defending party's consent. ${ }^{99}$ This process is hugely different from common international courts proceeding wherein states can only be sued before an international court if they have agreed to the jurisdiction of that court or tribunal. ${ }^{90}$

Under dispute settlement process, Indonesia has actively involved in the WTO cases. Since 1998 Indonesia has been a respondent for 10 cases, a complainant for 10 cases and a third party for around 17 cases. ${ }^{91}$ The following table shows how Indonesia has involved in the WTO case.

\subsubsection{Investment Agreements Have Provided Investor-State Dispute Settlement (ISDS)}

The existence of international dispute settlement will significantly determine the decision to invest abroad. Besides economic aspects, an investor will carefully calculate the level of risk in a particular country ${ }^{92}$ Specifically, without having provided stable and predictable law, an investor would be a subject to arbitrary, unpredictable, or otherwise unfair measures, such as unfair factory expropriation and heavy regulatory burdens. ${ }^{93}$ Moreover, in particular developing countries, government can be labile or corrupt and the 'rule of law' may not be properly implemented. ${ }^{94}$ On these grounds, although a host country has regulated dispute settlement procedures and remedies, 95 they would not be sufficient to resolve investor's dispute with the host country. ${ }^{96}$

The presence of the ISDS under investment treaties denoted a considerable shift under international investment law discourse through the recognition of non-state actors. ${ }^{97}$ In the past, under the diplomatic protection scheme, an investor could only sue the host state who assumed breach of commitment through one's home state that take action on one's behalf. 98 Through the ISDS, an investor could hold host state responsibility for any violation of their international obligation without depending on the intervention investor's home state. ${ }^{99}$

89 David Unterhalter. "What Makes the WTO Dispute Settlement Procedure Particular: Lessons to be Learned for the Settlement of International Disputes in General?" in Rüdiger Wolfrum and Ina Gätzschmann (eds). (2013). International Dispute Settlement:Room for Innovations?. New York: Springer, p. 6.

90 Ibid.

91 World Trade Organisation, Dispute Settlement: Disputes by country/territory. Available from: https://www.wto.org/english/tratop_e/dispu_e/dispu_by_country_e.htm [Accessed December 7, 2017].

92 Stephan W. Schill, "Private Enforcement of International Investment Law: Why We Need Investor Standing in BIT Dispute Settlement" in Michael Waibel, et al (eds). (2010). The Backlash Against Investment Arbitration. South Holland: Kluwer, p. 31.

93 Eric A. Posner and Alan O. Sykes. (2013). Economic Foundations of International Law. Harvard: Harvard University Press, p. 288.

94 Ibid.

95 Peter Muchlinski, "Policy Issues” in Peter Muchlinski, Federico Ortino, and Christoph Schreuer (eds). (2008). The Oxford Handbook of International Investment Law. Oxford: Oxord University Press, p. 41.

96 Ibid.

97 Jeswald Salacuse. (2010). The Law of Investment Treaties. Oxford: Oxford University Press, p. 11

98 Ibid.

99 Stephan W Schill, "Private Enforcement of International Investment Law: Why We Need Investor Standing in BIT Dispute Settlement" in Michael Waibel, Asha Kausal et al. (2010). The Backlash Against Investment Arbitration. South Holland: Kluwer, p. 30. 
The next rationales relating to how ISDS grant an investor what have been called as 'direct rights theory' wherein the substantive rights of an investor 'belong to the claimant investor itself ' instead of investor's home state. ${ }^{100}$ 'Direct rights theory' cover investor's ability to gain a successful claim although one's home state assumed that the court had no strong jurisdiction. ${ }^{101}$ Also, an investor could waive one right to undertake a claim. 102 Under this theory, there is no a compulsory requirement for an investor to exhaust domestic remedies prior to submitting a claim. ${ }^{103}$ Moreover, in the calculation of compensation, this process only considers the injury of an investor itself and not an investor's home state. 104

\section{Evidence of the Impact of Trade and Investment Agreements in Indonesia}

\subsection{Impact on Trade and Investment Flows}

In practice, some empirical data show how trade agreements have increased trade flows. Chirathivat (2002) simulated the impact of liberalisation of tariff and non-tariff ASEANChina Free Trade Agreement (ACFTA) separately. ${ }^{105}$ The study revealed that tariff liberalisation led to an increase of ASEAN exports to China by 53 per cent, while China's exports to ASEAN would increase by 23 per cent. ${ }^{106}$ Non-tariff liberalisation would increase ASEAN exports to China amounted to 187 per cent and Chinese exports to ASEAN by 34 per cent. 107 Diermen, Basri and Sahan (2011) analysed how ACFTA increased each country's exports to the other up to 70 per cent. 108 The highest increase of export was machinery and transport equipment sectors in China, and agricultural and mineral sectors in Indonesia. ${ }^{109}$

In 2012, the Fiscal Policy Agency ('FPA') of the Ministry of Finance of Indonesia analysed the impact of regional trade agreements that involved Indonesia. ${ }^{110}$ ASEAN- Korea FTA would expedite trade between ASEAN and Korea wherein Indonesia and Malaysia would benefit nearly half of the growth of trade between ASEAN and Korea. ${ }^{111}$ In Indonesia-Japan FTA, this study analysed if the exports of Indonesia to Japan increased approximately 5.23 per cent, meaning an increase of 1.58 times more than if Indonesia did not join Indonesia-Japan FTA. ${ }^{112}$ As regards to ASEAN-India FTA, this study pointed out Indonesia's export commodities, such as vegetable oil and fats, motor vehicles and parts, forestry, fruit, nuts had increased above 10 per cent during 20102011.113

\footnotetext{
100 Jeswald Salacuse, loc.cit.

101 Tania Voon, Andrew Mitchell and James Munro. (2014). “Parting Ways: The Impact of Mutual Termination of Investment Treaties on Investor Rights". ICSID Review, 29:455.

102 Ibid.

103 Ibid.

104 Ibid.

105 Suthipand Chirathivat. (2002). "ASEAN-China Free Trade Area: Background, Implications and Future Development". Journal of Asian Economics, 13:680.

106 Ibid.

107 Ibid.

108 Peter van Diermen, M Chatib Basri and Erinch Sahan. (2011). “Trade, Aid \& Development in Indonesia: A discussion paper". Prepared for AusAID-Indonesia Program, p. 1.

109 Ibid., p. 31.

110 Badan Kebijakan Fiskal. (2012). Free Trade Agreement (FTA) E Economic Partnership Agreement(EPA), dan Pengaruhnya terhadap Arus Perdagangan dan Investasi dengan Negara Mitra. Jakarta: Kementerian Keuangan, p. 3.

111 Ibid., p. 22.

112 Ibid., p. 43.

113 Ibid., p.94.
} 
Although increasing trade flows, some empirical data have expressed some concerns. Salidjanova and Iacob Koch-Weser (2015) examined China's relative significance for individual ASEAN countries.114 For trade balance, Indonesia has been experiencing a trade deficit with China since 2007. ${ }^{115}$ Specifically, China's import to Indonesia consistently increased from over $\$ 4$ billion in 2003 to $\$ 12.6$ billion in 2007, and increased to nearly $\$ 37$ billion in 2013.116 Kustiari and Hermanto (2016) then assessed the potential impacts of Indonesia-India FTA on the agricultural sector. ${ }^{117}$ Only vegetable, fruit and vegetable oil have shown an increase on export.118

According to Data from the Ministry of Trade (2016), Indonesia has a trade surplus with the following trade agreements' partners: Cambodia (15,05 per cent), Vietnam (6,47), Lao $(4,40)$, New Zealand $(0,97)$, and Philippines $(0,41)$. However, Indonesia has experienced a trade deficit with its partners, including Korea (-12,98 per cent), Japan $(-12,51)$, Singapore $(-7,43)$, Malaysia $(-6,71)$, Thailand $(-5)$, India $(-4,25)$, Australia $(-4,20)$ and China $(-2,54) \cdot{ }^{119}$

With respect to investment flows, Thangavelu and Findlay (2011) assessed whether PTAs have a differential impact on FDI flows in the Asia-Pacific region. ${ }^{120}$ The empirical results pointed out a positive connection between participation in ASEAN FTA and FDI inflows into the Southeast Asian region. ${ }^{121}$ The increase of FDI inflows then also determined by the treatment of investment, especially sectoral barriers to investment in manufacturing and services sectors.122 Diermen, Basri and Sahan (2011) then predicted that Indonesia-Australia FTA would increase FDI flows by 0.91 per cent in Indonesia's mineral and energy sector. ${ }^{123}$ Next, Wignaraja (2013) analysed that AFTA has increased FDI by 36 per cent in Indonesia. ${ }^{124}$

OECD (2010) revealed the enormous gap across regions within Indonesia in relation to FDI inflows. ${ }^{125}$ Java collected 60 per cent of FDI projects on an approval basis from 1992 to 2006.126 Sumatra was the second most attractive region for foreign investors, collecting 21 per cent of total FDI with the majority projects had been in the province of Riau. ${ }^{127}$

114 Nargiza Salidjanova and Iacob Koch-Weser. (2015). “China's Economic Ties with ASEAN: A Countryby-Country Analysis". U.S.-China Economic and Security Review Commission: Staff Research Report, p. 3.

115 Ibid., p. 17.

116 Ibid., p. 18.

117 Reni Kustiari and Hermanto. (2016). “The Impact of the Indonesia-India Free Trade Agreements: a CGE Analysis". Paper Presented at the 15th International Convention of the East Asian Economic Association: Sustainable and Inclusive Development in Asia and the Global Economy, 5-6 November 2016, Bandung, p.3.

118 Ibid.

119 Ministry of Trade, Balance of Trade With Trade Partner Country: Period 2011-2016. Available from: http://www.kemendag.go.id/en/economic-profile/indonesia-export-import/balance-of-trade-with-trade-partnercountry?negara=122 [Accessed January 4, 2018].

120 Shandre M. Thangavelu and Christopher Findlay, "The Impact of Free Trade Agreements on Foreign Direct Investment in the Asia-Pasific Region" in Christopher Findlay (ed.) (2011). ASEAN+1 FTAs and Global Value Chains in East Asia. Jakarta: ERIA, p.115.

121 Ibid., p. 124.

122 Ibid.

123 Peter van Diermen, M Chatib Basri and Erinch Sahan, op.cit.,p. 32.

124 Ganeshan Wignaraja. (2013). "Regional Trade Agreements and Enterprises in Southeast Asia". Asian Development Bank Institute Working Paper 442, p. 10.

125 Organisation For Economic Co-operation and Development. (2010). OECD Investment Policy Reviews Indonesia 2010. Paris: OECD, p. 58.

126 Ibid.

127 Ibid. 
From 2006, 85 per cent of the total FDI project was in Java, especially in the Jakarta Capital Region. ${ }^{128}$ Next, Sumatra has collected 11 per cent of total FDI projects that nearly half of investment has gone to Riau. ${ }^{129}$

\subsection{Impact on Development}

Some studies have identified how trade agreements have reduced poverty. First, Robilliard and Park et al (2008) explained how ASEAN-China FTA would benefit Indonesia through greater competition, lower consumer prices, and increased productivity. ${ }^{130}$ Similarly, Center of International Economics (2012) estimated IndonesiaAustralia FTA would also reduce poverty although its impact was likely to be varied depending on location and industry sector. ${ }^{131}$ A study from the Ministry of Trade of Indonesia (2011) showed how a trade agreement increased a competitiveness of Indonesian products. ${ }^{132}$ By using Constant Market Share Analysis ('CMSA'), this study examined the competitiveness of Indonesian manufacturing products after the implementation of Indonesia- Japan FTA. ${ }^{133}$ The result revealed the increase of competitiveness in the following products: fish products, cocoa, garments, and furniture. ${ }^{134}$ Nevertheless, the competitiveness of shrimp and plastic products has decreased after the implementation of this bilateral agreement. 135

Some empirical data also revealed some concerns. Robilliard and Robinson (2006) admitted although the data on poverty reduction were positive in relation to the number of people move out from poverty, the overall impact of trade liberalisation could not be positive as this study neglected the cost of temporary unemployment caused by displaced workers in some sectors. ${ }^{136}$ ILO (2013) then revealed that high unemployment still took place in Indonesia, particularly among women, the educated workforce and youth, reflecting the benefits of trade liberalisation have not been equal among age, gender and groups. ${ }^{137}$

As regards to FDI, some empirical data showed its significant benefit for development. Robertson (2009) examined the role of FDI and the working conditions in Indonesia, covering income, facilities, safety, transportation, and medical benefits. ${ }^{138}$ The result pointed out that the foreign-owned companies provided higher working conditions than local companies. ${ }^{139}$ Similarly, Lipsey and Sjöholm (2010) explained that foreign-owned

128 Ibid.

129 Ibid.

130 Donghyun Park, et al. (2008). "Prospects of an ASEAN-People's Republic of China Free Trade Area: A Qualitative and Quantitative Analysis". ADB Economics Working Paper Series 130, p. 17.

131 Centre for International Economics, op.cit., p. 33-34.

132 Kementerian Perdagangan Republik Indonesia. (2011). Kajian Dampak Kesepakatan Perdagangan Bebas terhadap Daya Saing Produk Manufaktur Indonesia. Jakarta:Kemdag, p. 186-187.

133 Ibid.

134 Ibid.

135 Ibid.

136 Anne-Sophie Robilliard and Sherman Robinson, "The Social Impact of a WTO Agreement in Indonesia" in Thomas W Hertel and L Alan Winters (eds). (2006). Poverty and the WTO : Impacts of the Doha Development Agenda. Geneva: The International Bank for Reconstruction and Development / The World Bank, p. 320.

137 International Labour Organisation. (2013). Trade and Employment: Country Report for Indonesia. Geneva: ILO, p. ix.

138 Raymond Robertson et al, "Globalization and Working Conditions: Evidence from Indonesia" in Raymond Robertson et al (eds). (2009). Globalization, Wages, and the Quality of Jobs: Five Country Studies. Geneva: The International Bank for Reconstruction and Development / The World Bank, p. 232.

139 Ibid. 
companies and foreign acquisitions in manufacturing plants have paid higher wages than domestic companies. ${ }^{140}$ OECD (2010) then denoted how FDI projects have generated much more employment. ${ }^{141}$ From 2006 to 2008, new FDI projects provided 645000 jobs, that was equal to 7 per cent of the increase in total employment. ${ }^{142}$

\section{Conclusion}

It has to be admitted that the existence of trade and investment agreements has been doubted due to the unequal development and poverty in some states across the globe. The rise of the spirit of national interest that has been reflected through the increase of trade barriers and the termination of agreements worsen the situation. Although these two depressed facts, Indonesia should keep its participation in trade and investment agreements, especially to realise its targets in economic growth and development. Looking at the theory and evidence of international trade and foreign direct investment, they have provided significant benefits, covering, the increase of jobs, less expensive products, transfer of technology, transfer of skills, the alleviation of poverty, GDP's increase. There have been four rationales of trade and investment agreements. Firstly, trade and investment agreements can avoid armed conflict; they have implemented nondiscriminatory principles; they have provided special and differential treatments for developing countries, and they have a fair and independent dispute settlement mechanism. Analysing the trade and investment agreements that involve Indonesia, they have positively affected trade and investment flows and development in Indonesia.

\section{References}

Adam Smith. (1976). An Inquiry into the Nature and Causes of the Wealth of Nations, Chicago: University of Chicago Press.

Andrew Mitchell and David Heaton. (2010). “The Inherent Jurisdiction of WTO Tribunals: The Select Application of Public International Law Required by the Judicial Function". Michigan Journal of International Law, 31: 559-619.

Andreas Dur, Manfred Elsig (eds). (2015). Trade Cooperation: The Purpose, Design and Effects of Preferential Trade Agreements. Cambridge: Cambridge University Press.

Badan Kebijakan Fiskal. (2012). Free Trade Agreement (FTA) dan Economic Partnership Agreement(EPA), dan Pengaruhnya terhadap Arus Perdagangan dan Investasi dengan Negara Mitra. Jakarta: Kementerian Keuangan.

David Ricardo. (1951). On the Principles of Political Economy and Taxation, Cambridge: Cambridge University Press.

David Trubek and Alvaro Santos (eds). (2006). The New Law and Economic Development: A Critical Appraisal. Cambridge: Cambridge University Press

Daniel Bodansky, Jessica C Lawrence. "Trade and Environment" in Daniel Bethlehem et al (eds.). (2009). The Oxford Handbook of International Trade Law. Oxford: Oxford University Press.

Eric A. Posner and Alan O. Sykes. (2013). Economic Foundations of International Law. Harvard: Harvard University Press.

\footnotetext{
140 Robert E Lipsey and Fredrik Sjöholm, Op.Cit., p.20.

141 Organisation For Economic Co-operation and Development. (2010). OECD Investment Policy Reviews Indonesia 2010. Paris: OECD, p.60.

142 Ibid.
} 
Edward D Mansfield and Brian M. Pollins (eds). (2003). Economic Interdependence and International Conflict: New Perspectives on an Enduring Debate. Michigan:University of Michigan Press.

ESCAP. (2007). Towards Coherent Policy Frameworks: Understanding Trade and Investment Linkages - A study by the Asia-Pacific Research and Training Network on Trade. Geneva: United Nations.

FA Mann. (1981). "British Treaties for the Promotion and Protection of Investments". British Yearbook of International Law, 52:241-254.

Ganeshan Wignaraja. (2013). “Regional Trade Agreements and Enterprises in Southeast Asia". Asian Development Bank Institute Working Paper 442.

GDA MacDougall. (1960). "The Benefits and Costs of Private Investment from Abroad: A Theoretical Approach'. Economic Record, 36: 25-32.

Giorgio Sacerdoti, et al. (eds). (2014). General Interest of Host State in International Investment Law. Cambridge: Cambridge University Press.

Hailay Gebretinsae Beyene. (2015). "Does International Trade Reduce Political Disputes?". Foreign Trade Review, 50:99-117.

Hanspeter Neuhold. (2015). The Law of International Conflict: Force, Intervention and Peaceful Dispute Settlement. Leiden: Brill Nijhoff.

Hernando De Soto. (2000). The Mystery of Capital: Why Capitalism Triumphs In The West and Fails Everywhere Else. London: Penguin Books

Huiya Chen, Deborah L Swenson. (2014). "Multinational Exposure and the Quality of New Chinese Exports". Oxford Bulletin of Economics and Statistics,76:41-66.

I Gusti Ngurah Parikesit Widiatedja and I Gusti Ngurah Wairocana. (2017). “The Lack of the Environmental Concern in Indonesia's Bilateral Investment Treaties". Hasanuddin Law Review 3(3): 231-245.

I Gusti Ngurah Parikesit Widiatedja and I Gusti Ngurah Wairocana. (2017). “The Rise of the Spirit of National Interest and the Existence of World Trade Organization Agreement: A Case Study of Indonesia". Padjajaran Journal of Law 4(2): 319-340.

International Labour Organisation. (2013). Trade and Employment: Country Report for Indonesia. Geneva: ILO.

Jeswald Salacuse. (2010). The Law of Investment Treaties. Oxford: Oxford University Press.

Jeswald W Salacuse. (2013). The Three Laws of International Investment: National, Contractual, and International Frameworks for Foreign Capital, Oxford: Oxford University Press.

John H Dunning. (1977). The International Allocation of Economic Activity. London: Palgrave Macmillan.

Joanne Gowa and Raymond Hicks. (2013). "Politics, Institutions and Trade: Lessons of the Interwar Era". International Organization, 67:439-467.

Joost Pauwelyn. (2014). "The Re-Convergence of International Trade and Investment Law: Causes, Questions, and Reform". American Society of International Law Proceeding, 108:255-258.

J G Merrills. (2011). International Dispute Settlement. Cambridge: Cambridge University Press. 
Julian Richards and Elizabeth Schaefer. (2016). Jobs Attributable to Foreign Direct Investment in the United States. Available from: http://www.trade.gov/mas/ian/ build/groups/public/@tg_ian/documents/webcontent/tg_ian_005496.pdf [accessed Dec 11, 2017].

Karen J Alter. (2014). The New Terrain of International Law: Courts, Politics, Rights. New Jersey: Princeton University Press.

Laura Alfaro et al. (2004). "FDI and Economic Growth: The Role of Local Financial Markets". Journal of International Economics, 64:89-112.

Martin Feldstein and Charles Horioka. (1980). “Domestic Savings and International Capital Flows". Economic Journal, 90:314-329.

Matthias Herdegen. (2013). Principles of International Economic Law. Oxford: Oxford University Press.

Margit Bussmann. (2010). “Foreign Direct Investment and Militarized International Conflict". Journal of Peace Research, 47(2): 143-153.

Mitsuo Matsushita et al. (2003). The World Trade Organization: Law, Practice, and Policy. Oxford: Oxford University Press 3rd ed.

Michelle Grando. (2009). Evidence, Proof and Fact-Finding in WTO Dispute Settlement. Oxford: Oxford University Press.

Nicholas DiMascio, Joost Pauwelyn. (2008). "Nondiscrimination in Trade and Investment Treaties: Worlds Apart or Two Sides of the Same Coin". American Journal of International Law, 102: 48-89.

Peter Van Den Bossche. (2010). The Law and Policy of the World Trade Organization: Text, Cases and Materials. Cambridge: Cambridge University Press.

Peter van Diermen, M Chatib Basri and Erinch Sahan. (2011). "Trade, Aid \& Development in Indonesia: A discussion paper". Prepared for AusAID-Indonesia Program.

Peter Muchlinski, Federico Ortino, and Christoph Schreuer (eds). (2008). The Oxford Handbook of International Investment Law. Oxford: Oxord University Press.

Przemyslaw Kowalski, Max Büge Kowalski, P. and M. Büge. (2013). “Assessing the Trade-Related Sources of Productivity Growth in Emerging Economies". OECD Trade Policy Papers, 158.

Raymond Robertson et al (eds). (2009). Globalization, Wages, and the Quality of Jobs: Five Country Studies. Geneva: The International Bank for Reconstruction and Development / The World Bank.

Roberto Echandi, Pierre Sauve (eds). (2013). Prospects in International Investment Law and Policy. Cambridge: Cambridge University Press.

Reni Kustiari and Hermanto. (2016). "The Impact of the Indonesia-India Free Trade Agreements: a CGE Analysis". Paper Presented at the 15th International Convention of the East Asian Economic Association: Sustainable and Inclusive Development in Asia and the Global Economy, 5-6 November 2016, Bandung

Roberto Echandi, Jana Krajcovicova, Christine Zhenwei Qiang. (2015). “The Impact of Investment Policy in a Changing Global Economy: A Review of the Literature", World Bank Policy Research Working Paper, 7437.

Rüdiger Wolfrum and Ina Gätzschmann (eds). (2013). International Dispute Settlement: Room for Innovations?. New York: Springer. 
Solomon Polachek and Jun Xiang. (2010). "How Opportunity Costs Decrease the Probability of War in an Incomplete Information Game". International Organization, 64: 133-144.

Sisira Jayasuria, Donald MacLaren and Gary Magee (eds). (2009). Negotiating a Preferential Trading Agreement: Issues, Constraints and Practical Options. Cheltenham: Edward Elgar.

Suthipand Chirathivat. (2002). "ASEAN-China Free Trade Area: Background, Implications and Future Development". Journal of Asian Economics,13:671-686.

Steffen Hindelang and Markus Krajewski. (2016). Shifting Paradigms in International Investment Law: More Balanced, Less Isolated, Increasingly Diversified. Oxford: Oxford University Press.

Tarcisio Gazzini and Eric De Brabandere (eds). (2012). International Investment Law : The Sources of Rights and Obligations, Leiden: Martinus Nijhofff Publishers.

Tania Voon. (2015). “Evidentiary Challenges for Public Health Regulation in International Trade and Investment Law". Journal of International Economic Law, 18:795-826.

Tania Voon, Andrew Mitchell and James Munro. (2014). "Parting Ways: The Impact of Mutual Termination of Investment Treaties on Investor Rights". ICSID Review, 29: 451-473.

Thomas W Hertel and L Alan Winters (eds). (2006). Poverty and the WTO: Impacts of the Doha Development Agenda. Geneva: The International Bank for Reconstruction and Development / The World Bank.

United Nations Conference on Trade and Development. (2016). World Investment Report 2016: Investor Nationality: Policy Challenges. Geneva: United Nations Publication.

Yong-Shik Lee et al (eds). (2011). Law and Development Perspective on International Trade Law. Cambridge: Cambridge University Press.

Zu'bi MF Al-Zu'bi et al. (2012). "Investigating the Effect of Foreign Direct Investment Technology Transfer on Mass Customization Capability in Jordan's Manufacturing Sector". International Research Journal of Finance and Economics, 94: 79-90. 